\title{
Local Language Numeracy Kindergarten Prototype Design to Support Home-based Learning During and Post COVID-19 Pandemic
}

\author{
Vusumuzi Maphosa \\ Lupane State University, Department of ICT, Zimbabwe \\ ORCID: 0000-0002-2595-3890 \\ Bekithemba Dube \\ University of the Free State, South Africa \\ ORCID: 0000-0003-4327-7838
}

Received: 9 May 2020

Accepted: 28 Jun 2020

\begin{abstract}
The outbreak of the coronavirus disease (COVID-19) has caused unprecedented global socio-economic disruptions. One of the areas negatively impacted is the education system. The country's over reliance on traditional face-to-face teaching has brought about serious challenges to policymakers who have to decide how learning would proceed in the absence of physical contact between the teacher and the learner. This has been exacerbated by the general lack of access to textbooks and other teaching and learning materials which makes it difficult for parents to assist with home schooling. The potential use of mobile apps to support and enhance early childhood learning has received little attention in developing countries such as Zimbabwe, yet its impact in supporting early childhood education would be enormous during and post the COVID-19 pandemic. The study seeks to develop a numeracy-based app prototype that uses a local language (IsiNdebele) in a classroom or home-based schooling in response to the COVID19 pandemic or other natural disasters or man-made situations that may make face-to-face interaction impossible. The analysis showed that kindergarten teachers had positive opinion towards the app as they perceived the prototype to be useful, easy to use, simple and that learners would be eager to use it. The results of this study can inform policymakers and educators on optimising technology based early teaching and learning at school and home.
\end{abstract}

Keywords: COVID-19, kindergarten, mobile apps, home-based learning, technology acceptance model

\section{INTRODUCTION}

The COVID-19 has become a global threat to humanity and taken the world by storm, reconstructing the terrain of every aspect of life (Akwa, Ning,\& Maing, 2020; Papapicco, 2020; Sintema, 2020), after its first outbreak in Wuhan city of Hubei province in the people's republic of China (Tanhan et al., 2020). By the $27^{\text {th }}$ of April 2020, there were slightly over three million confirmed cases of COVID-19, and 211,321 deaths globally while Zimbabwe had recorded 31 cases and 4 deaths (Roser et al., 2020). The global academic calendar was disrupted as schools and higher education institutions shutdown and adopted precautionary measures to contain the spread of the virus through social distancing (Demuyakor, 2020). Zimbabwean education system was not an exception, igniting the need to explore new ways of teaching such as online to compensate the lost time due to COVID 19. Schools were prematurely closed on the 24th of March 2020 to limit physical contact and thus contain the spread of the acute respiratory syndrome coronavirus 2 (SARS-COV-2), the virus that causes COVID-19. Among other measures that have been adopted by governments across the world to contain the spread of COVID-19 include social distancing, closure of non-essential services and frequent 
testing and wearing of protective gear and have been known as a state of lockdown. Given this context, there is new normal, which Usak et al. (2020, p. 180) describe it as "fireplace where we all are burning", yet there is need to find alternative to continue life such as resorting to online learning.

A coalition of donor agencies specializing in education reported that Zimbabwe's 4.56 million school going children aged between three and 12 years were affected by the school closure while 1.2 million will require emergency and specialized learning and teaching (OCHA, 2020). Before the COVID-19 outbreak, the country's education sector was battered by the country's prolonged economic crisis, drought, high levels of unemployment, limited supply of electrical power and fuel as well as the humanitarian crisis by Cyclone Idai (UNICEF, 2020). Most developing countries are still using the traditional education system which is dependent on the teacher and the classroom Mangwaya et al. (2013). Some developing countries like Indonesia are using ICTs to maintain and continue teaching and learning during the COVID-19 pandemic (Mailizar, Maulina, \& Bruce, 2020). Over reliance on the traditional face-to-face teaching in Zimbabwean schools has brought about serious challenges to policymakers who have to decide how learning would proceed in the absence of physical contact between the teacher and the learner. This has been exacerbated by the general lack of access to textbooks and other teaching and learning materials which makes it difficult for parents to assist with.

For many years, education was mainly influenced by resources such as print, radio and television, but the introduction of apps, e-books and video streaming is a game changer in the shaping of the learning environment. Since digital media has evolved to support nearly every aspect of human life, it is critical to utilize it to support the educational needs of young children. Among children and regardless of their economic background, the use of digital media is a very popular and common activity of their lives. In the wake of the COVID-19 pandemic, there is need to leverage technology and offer learners an opportunity to learn regardless of geographic boundaries, and to do so at whatever time that may be convenient to them. Sintema (2020) noted that most developing countries were not ready to implement online education countrywide. Thus, our paper becomes part of the strategies to ensure that learning continues despite the trajectories of COVID-19 at Kindergarten level.

At the core of the digital revolution are smartphones which have greatly influenced human life. Studies have shown that an average smartphone owner spends an average of 150 minutes using apps a day and this figure has most likely gone up (Annie, 2017). Livingstone et al. (2014) have posited that smartphones have become popular with pre-scholars as they offer intuitive screens with aesthetic graphics, and have the ability to load several freely available downloadable apps and mobility suited pre-scholars. Young children are more comfortable with smartphones because of their touchscreens and small sizes compared to personal computers and laptops. Papadakis et al. (2016) concur that smartphones are popular among young children because of the large screen displays relative to their size, quality graphics, multimedia support, internet connectivity and their light weight, among others. The operation of smartphones is also easy and does not rely on dexterity-based motor skills associated with the personal computer's peripheral devices such as the keyboard or mouse (Kucirkova, 2014).

The term digital native was coined by Prensky (2001), who later described today's learners as "iLearners" whose lives have been embedded in digital devices which have become part of their everyday living (Prensky, 2010). The past few years have seen a sharp increase in the availability of smartphones and tablets and this has resulted in increased access to content by young children (Center Pew Research, 2018). A study by Guernsey (2014) reiterated that smartphones have become a part of every family including the economically disadvantaged households; and have been embraced by young children who are growing immersed in digital technologies. This is good news for home-based technology driven learning in the wake of the COVID-19 which has disrupted normal activities such as school-based learning. Papadakis and Kalogiannakis (2017) note that $21^{\text {st }}$-century children grow up in digital media-rich homes where these devices influence the life of family members. Cohen et al. (2011) concluded that young children explore smartphones and apps instinctively to learn in natural ways through playing, trying and repeating until they have mastered. This has led to the development of several apps that promote school and home-based learning. Some of the apps have been developed for entertainment purposes to engage the children and appeal to their playfulness. 
Plowman et al. (2012) concluded that children who had access to digital media at home performed better than those who only accessed digital media from the school only; and they also observed that the home environment allowed young children to ask questions and also learn by observing family members working on their devices. The parents in this study also believed that the early adoption and use of digital media by young children had a strong bearing on the children's education and future careers (O'Connor, 2016). A similar study by Vittrup et al. (2014) found out that parents strongly believed that restricting young children from using digital media would academically and technologically disadvantage them as they miss opportunities to prepare for jobs of the future. Bus et al. (2019) concluded that apps boosted literacy and numeracy skills for young children and in some cases young children could learn on their own without the support of their parents. Thus, the study has sought to design and evaluate a preliminary and simple IsiNdebele prototype that teaches kindergarten children basic numeracy skills such as how to count natural numbers in their language. These numbers are mastered by relating them to real world objects. As the country is on lockdown, parents could use this app at home for teaching children and we hope that this may raise the interest of the parents who may then demand the future use of such technology in the classroom.

\section{Smartphones as the Preferred Digital Technology for Children in Kindergarten}

Of all the digital technologies accessible to young children, mobile phones are the most popular and research indicates that these devices are capable of supporting teaching and learning (Papadakis \& Kalogiannakis, 2017). Surveys that were conducted in the United States of America (USA) indicate that almost all children under eight years have access to a smartphone at home (Rideout, 2017) and this is a trend worldwide, including in developing countries (Cristia \& Seidl, 2015). Smartphones have been used in Ethiopia, Uganda and South Africa to support early learning for children from remote and rural communities and results revealed that these children performed better in letter reading than those who had no access to smartphones (Pugh, McCardle, \& Stutzman, 2018).

Mobile apps have been used to package learning material such as letters, numbers and words; and their biggest advantage is the ability to support rich multi-media content which is conducive for young learners (Bus et al., 2019). Mobile apps can support activities such as phoneme and grapheme which strengthen reading among young learners (Jones, 2015). The introduction of apps can provide a wholesale environment for learning through a vast array of multi-media resources and instant feedback at almost no cost (Berson \& Berson, 2010). Bus et al. (2019) have noted that apps have an advantage of providing learning resources from math to physical education in an accessible and cheap way regardless of the family's well-being.

The 21st century has witnessed vast changes in educational technology, and this has seen the development of a variety of apps that can support reading, literacy, gaming etc. Chiefly, the integration of Information Communication Technologies (ICTs) to support the entire education ecosystem has raised interest among policymakers and educators. O'Connor (2016) highlights that the resistance that many parents had regarding use of digital media by their children is slowly diminishing as they realize the new territories of learning and expression that these devices possess. The introduction of technology to children allows them to learn in a playful and engaging environment, which enthuses learners and makes them concentrate when performing their learning tasks. In the context of the current COVID-19 outbreak, the views of Athanaselis et al. (2014) are apposite - technology can offer adaptive teaching and learning when the teacher and learner cannot engage physically or there is limited teacher involvement.

During the COVID-19 lockdown, mobile apps can enable children to learn at their own pace with supervision from their parents and guardians until they reach the mastery levels. The introduction of digital technologies in the lives of young children is not without controversy. Some parents have raised fears that apps can negatively impact on children's innocence and expose them to inappropriate content as well as ergonomic factors such as eye strain and lack of exercise (O'Connor, 2016). A study by O'Connor (2016) revealed that $26 \%$ of the respondent parents raised concerns that their young children could be addicted to and be over reliant smartphones. Similarly, Marsh et al. (2018) reported that about $6 \%$ of parents felt uncomfortable with their young children being exposed inappropriate content. There have also been concerns about young 
children spending several hours viewing screens. A study by Vanderloo (2014) found that children between four and seven years spent up to 7 hours a day viewing screens.

\section{Home-based Learning}

In situations "where the students are not allowed to go to school, the alternative is to move from traditional to online education" (Basilaia \& Kvavadze, 2020, p. 2). To implement traditional online, home learning is the alternative. Home-based learning plays a critical role in the development of young children, particularly their early reading skills, yet our current education system does not present opportunities to foster this besides parents assisting their children with homework. Institutions that have invested in home-based learning are reaping rewards during this COVID-19 lockdown. The pervasiveness of mobile devices within homes has opened a corridor for home-based learning. Scholars have noted that digital natives are becoming comfortable with using digital media at home, school and the community (Berson \& Berson, 2010). In their study, Cheung and Pomerantz (2012) concluded that home-based learning played a critical role in the early language and phonological development of young children particularly the poor families. A similar conclusion was by Paratore et al. (2011) who posited that parent engagement was critical in young children's development and set a solid foundation for later school achievement. In his study, Neumann (2016) revealed that children who learnt at home acquired early literacy skills compared to children who did not.

The ubiquitous nature of digital media can help parents in assisting their children at home, Berkowitz et al. (2015) reported that first grade learners who used a math app at bedtime significantly performed better than those in a control group. Strouse and Ganea (2017) reported that parents used digital media to engage their children aged one to four years in reading activities daily. Some scholars have observed that children effortlessly engaged with digital media at home and in some instances, parents' guide and help their children in entertainment and educational apps (Chaudron et al., 2015; Papadakis et al., 2019). Similarly, Neumann (2016) established that some young children were capable of using digital media on their own at home, but the scaffolding role played by parents and teachers was critical. This was corroborated by Cabell et al. (2019) who concluded that young children's literacy skills could be improved by better parent engagement and digital media provides a palatable platform to parents and young children.

Parents' attitudes are critical in the use of digital media in the classroom. Papadakis et al. (2019) have reported that parents who used digital technology at home supported its use at kindergarten. Similarly, Stephen et al. (2013) noted that parents who allowed young children to play with smartphones at home had positive attitudes towards their use in pre-school. Papadakis et al. (2019) concluded by noting that parents felt that if their children did not use digital media at home they may be left behind when they go to primary school. In a similar study, Plowman et al. (2012) reported that young children were accustomed to digital media and parents felt that this was a good foundation for their early primary education. Nikken and Schols (2015) reported that parents remained gatekeepers on the type of digital content their children accessed at home.

Plowman et al. (2008) reiterated that the benefits that preschoolers enjoy from using technology are temporary in the absence of guidance by the teacher. During the COVID-19 lockdown it is important for parents to support and be involved in the teaching and learning of their children especially preschoolers to help them achieve their learning. In their study in Malawi, Pitchford et al. (2018) posited that tablets could be provided to pupils for use after school and at home to foster home-based learning. Parents will play a critical role in ensuring that their young children could learn through digital media during the COVID-19 lockdown.

\section{LITERATURE REVIEW}

Digital technologies have affected every facet of human life, extending to educational settings, yet very few studies have been conducted in Zimbabwe to evaluate the effectiveness of apps to complement lesson delivery when it is not possible to have face-to-face contact with the learners. The effect of the COVID-19 pandemic is likely be enormous on the Zimbabwean education system which is yet to recover from multiple 
crises that have bedeviled the country such as economic meltdown, drought, currency instability and Cyclone Idai (OCHA, 2020). Also, the probability is high that the education sector would be one of the last sectors to open as it is difficult to observe social distancing in schools and colleges.

While fixed telephone penetration rates are less than three percent in Zimbabwe, the mobile phone penetration is very high, with the rate in urban areas reported at about $110 \%$ at one time, with that of the rural areas standing at about 75\% (Lancaster, 2016).

Zimbabwe's smartphone penetration rate reached $55 \%$ by August 2018 and this figure was expected to grow driven by the popularity of social media (Technomag, 2018). The mobile phone has therefore managed to bridge the digital divide in Zimbabwe, and this has been corroborated by Rideout (2017) who points out that while economically disadvantaged communities had challenges in accessing a computer, almost every household has a mobile phone. Policy makers could therefore take advantage of these statistics and ensure that education institutions deploy apps to support teaching and learning during the COVID-19 lockdown.

High levels of mobile phone penetration rates present an opportunity to introduce mobile apps to complement traditional teaching (Livingstone et al., 2014; Center Pew Research, 2018). The MIT Media lab developed digital learning material targeting over 72 million children with no access to schools and was successfully deployed in remote regions of Ethiopia with encouraging and promising results (Wolf et al., 2014). Papadakis et al. (2019) reported that smartphones had become present in every household regardless of its economic well being and was influencing the growth and development of children. The intuitive nature of smartphones and easy development of apps makes the introduction of digital media to young children possible. The rapid advancements in mobile technology and apps presents an avenue to deliver educational content to children in fascinating ways at school and home (Kucirkova \& Zuckerman, 2017). In developed countries, pre-school apps have rapidly evolved and emerged into a critical medium for providing educational content for children (Lee \& Cherner, 2015; Papadakis \& Kalogiannakis, 2017).

The disruptive impact of mobile phone technology has been enormous, influecing our way of life and this has not spared the delivery educational content. Digital technologies have transformed education by placing the learner at the centre of their learning experience compared to the traditional instructor centred paradigm (Lowyck, 2014). Some notable advantages of educational apps for young children are intiutivity and engagement which fosters usability (Flewitt, Messer, \& Kucirkova, 2015). Today's children spend reasonable time glued to digital devices, using them for playing, learning and communication in an exciting way (Papadakis \& Kalogiannakis, 2017). Smartphones are interactive and provide friendly interfaces which are appropriate for supporting the early developmental needs of young learners, and are appropriate for both the school and home environments (Gordon \& Williams-Browne, 2016).

Digital media convey textual, auditory and visual information and Paivio (2014) posits that processing auditory and visual information enables high order learning as it supports processing of verbal and non-verbal information. Similarly, Elimelech and Aram (2019) have concluded that digital literacy games can improve and enhance young children's literacy at kindergarten. Empirical evidence from their study also revealed that an experimental group that used auditory and visual media scored higher on spellings compared to control group which had access to print. This means that apps that support multimedia can improve literacy levels of young children. Children from remote Ethiopian villages who were given tablets and smartphones were able to self-teach themselves letters of the alphabet in a short time and could write using sticks on the ground as they did not have access to a pencil and paper before (Wolf et al., 2014).

Livingstone et al. (2014) have observed that preschoolers in the United Kingdom (UK) could independently locate information and identify basic words on their tablets. Also, a study by Berkowitz et al. (2015) concluded that children who used a math app more often had better results compared to a control group which did not. A study by Neumann (2014) revealed that preschoolers who accessed smartphones at home performed better in writing and reading compared to those who did not and it is evident that smartphones and apps may support learning during the COVID-19 pandemic. 
Table 1. Questionnaire questions

\begin{tabular}{ll}
\hline Number & Statement \\
\hline 1 & I found it easy to use and easy to remember. \\
2 & The app is simple to use and will be a great tool to learners. \\
3 & I intend to use the mobile app in and out of the classroom \\
4 & The graphics can enhance children's learning \\
5 & The app provides effective visual hinting \\
\hline
\end{tabular}

Marsh et al. (2005) as cited by O'Connor (2016) observed that preschoolers were using digital media at home and noted that most parents were involved and supported their children in their learning endeavors. The support rendered to young children at home is evidence that parents believe in the potential of digital media in enhancing their development and learning (Flewitt, 2012). In another study, O'Connor (2016) reported that social interactions with family members through digital platforms developed children's dispositions and competencies that supported their learning.

A study that was conducted in Malawi revealed that tablets alone could not improve performance of children but rather the apps that were installed improved the children's learning outcomes though passing some quiz in the app (Pitchford et al., 2018). There is belief that young children will prefer entertainment apps compared to educational ones. However, Papadakis et al. (2016) found out that young children used educational apps more than entertainment ones.

\section{METHODOLOGY}

The present study was conducted during the COVID-19 lockdown and as such, it was difficult to follow the appropriate app development methodology as explained in the limitation's sections below. Ten kindergarten teachers were randomly selected to evaluate the app prototype. The respondents were aged between 26 and 45 years of age, having completed a Diploma in Childhood Development. The evaluation was based on the Technology Acceptance Model (TAM). Two important individual constructs of the TAM are perceived usefulness (PU) and perceived ease of use (PEOU), which support attitudes (At) that determine the utilization of a certain information system or technology (Davis, 1989). The TAM evaluates user acceptance of a wide range of end-user computing technologies by a target population. The questions related to ease of use and usefulness of the app are presented in Table 1. The questionnaire survey based on the TAM constructs used a five-point Likert scale whose values ranged from 1 (Strongly Disagree) to 5 (Strongly Agree) while 3 signaled indecision.

\section{Smartphones a Technology of Choice for Children}

A survey by Rideout (2017) carried out in some European countries revealed that $42 \%$ of children under 8 years owned their own smartphone while $95 \%$ had access to a smartphone from their home. Another study in the UK by Marsh et al. (2018) showed that $36 \%$ of the children between three and five years owned a smartphone. Another study carried out in four European countries by O'Connor (2016) found that about $66 \%$ of children under 3 years had daily access to a smartphone or tablet. In Greece, a study revealed that $55 \%$ of the parents were willing to offer their mobile phone to their children (Papadakis et al., 2019). In a survey of children between three and six years in Turkey, Genc (2014) reported that over $50 \%$ of the children used the smartphone daily; while Meyer et al. (2019) reported that children less that eight years in the UK spent an hour per day using smartphones; and Ebbeck et al. (2016) reported that Singaporean children under seven years also accessed various apps daily on smartphones.

Previous studies have documented the popularity of smartphones and apps among children. Nielsen (2012) reported that $70 \%$ of USA families with children aged 12 years and younger owned a smartphone which they shared with them. The study further reported that children downloaded games and educational apps. In a related study in the USA whose sample was 350 children, it was observed that about $97 \%$ of the children 
used smartphones for playing games and learning (Kabali et al., 2015). Young children use smartphones for a variety of reasons such as watching television and playing games and studies revealed that children spent an average of 80 minutes per day on the phone (Marsh et al., 2018). In terms of technology access, children in Zimbabwe have more access to a mobile phone, as its ownership was reported to be over $90 \%$ compared to a computer or laptop whose ownership is about $3 \%$ of the population (POTRAZ, 2019).

\section{COVID-19 Pandemic: Challenges and Prospects}

In response to the COVID-19 pandemic, parents should harness the potential of digital media which has already found itself in the hands of children to support their learning needs and foster their development. Unfortunately, the Zimbabwean government has proposed to use radio for lesson presentation (SundayNews, 2020), which may not work well as children would prefer continuous and bi-directional learning with instant feedback. The government is also considering printing hard copy materials for students who may not have access to digital media and no time frames have been put, yet a significant portion of the school year has been affected.

Hoffman and Paciga, (2014) note that the introduction of tablets and e-books to young children creates more awareness than the usage of printed material. Thus, exposure to digital media by children compliments their educational development and experience. Other scholars have commended the introduction of smart devices to young children, claiming that this has laid a solid foundation for 21st-century skills and lifelong learning. Teachers require new skill-set to be able to administer digital media in the classroom and policymakers should immediately introduce this technology for the growth of the country's education system.

The introduction of digital media to young children will not be without resistance in developing countries, and scholars such as Bus et al. (2019) have contended that there is need to produce scholarly output that outlines the benefits of educational apps compared to traditional teacher centered learning. This would also assessment of educational apps meant for children so that educators and policymakers could determine their impact on the children's educational development.

\section{Introducing the IsiNdebele Numeracy Kindergarten App}

The ability of digital devices to support independent learning when traditional face-to-face meeting is not practical provides an opportunity for the use of apps as was noted by Simon et al. (2013). The purpose of the IsiNdebele Numeracy Kindergarten App is to teach kindergarten basic numeracy skills by teaching learners how to count using real world objects such as fruits. The development of the porotype was in line with work by Zaranis et al. (2013) who asserted that software developed for children should be easy for them to handle and user friendly.

The first screen of the app allows the learner to enter their name. This helps the learner to master their name as well as handling of the media. The app contains a few pages that provide simple visual content that kindergarten children can understand and learn numeracy in their mother language as shown in figure 1. Zaranis et al. (2013) highlighted that the software should combine animation and sound to allow learners to understand the instructions. The sound created by the app adds an element of fun and creates an environment for learners to explore the app with ease. Learners are asked to count and state the number of given objects in their local language.

The app tests the learners' ability to count natural numbers based on associated real-world objects. When learners have learnt how to count objects, they also have to identify the corresponding number for the items counted - "Kungaki?", "Khetha inombolo eqondileyo" in IsiNdebele. The app can also teach learners how to do basic addition and subtraction in isiNdebele. There are several questions that learners are expected to answer e.g. counting the number of real-world objects such as bananas or potatoes. The app has buttons that allow the learner to move to the next stage and provides simple feedback through graphic characters to indicate if the learner got the correct answer or they should try again. When a learner makes a mistake, the app provides feedback such as try again and when they correctly count, they are congratulated. This is 


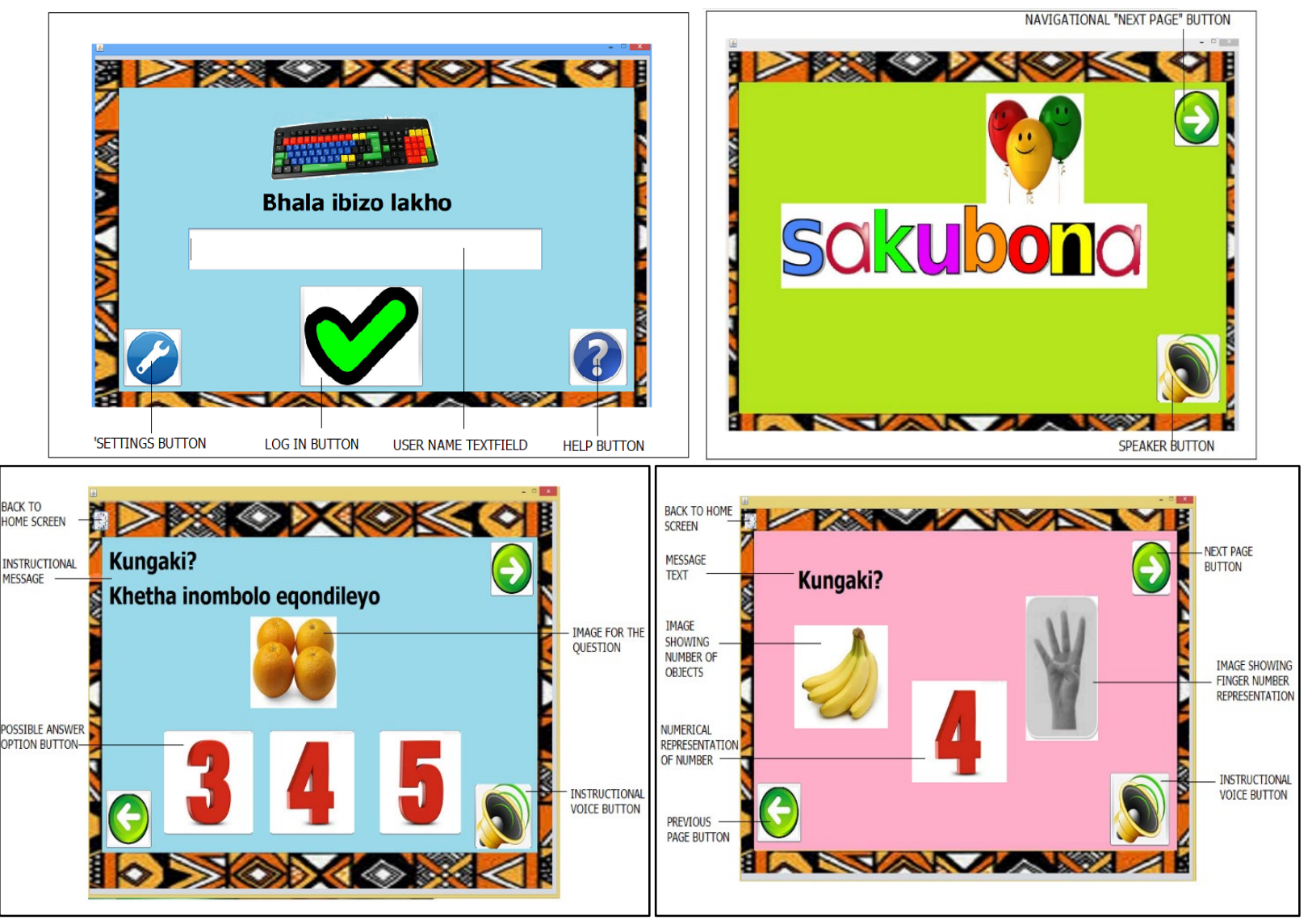

Figure 1. Prototype screens

consistent with an evaluation by Zaranis et al. (2013) who contended that all apps they evaluated provided some feedback on completion. Furthermore, the app is downloaded onto the smartphone to enable offline access; and this makes it suitable for use in low income populations or environments with low connectivity.

\section{RESULTS AND IMPLICATIONS}

The teachers perceived the prototype useful through a mean score of 4.5 out of 5 . Regarding the perception of teachers on the ease of use of the prototype version, a mean score of 4.4 was recorded. The teachers believed that learners will eagerly use the prototype through a mean score of 4.2 . The simplicity and the potential of the prototype to support learning was evaluated and a mean score of 4.7 was recorded. Visual hinting is an important aspect for early learning, teachers agreed that the app provided effective visual hinting through a mean score of 4.6. The teachers intended to use the mobile app in and out of the classroom and this was shown by a mean score of 4.6. The positive attitude and perceived ease of use will have a strong influence on the adoption of the prototype. One innovation provided by this app is the use of the mother language to teach kindergarten children numeracy. The results show that numeracy apps have the potential of improving early childhood learning. These preliminary evaluation results show that there is need to develop apps that can facilitate numeracy learning for kindergarten children during natural disasters like the COVID-19 and other man-made situations that render face-to-face teaching and learning impossible. Apart from this COVID 19 is causing many biopsychosocial, spiritual and economic issues for almost all of humanity (Tanhan et al., 2020), hence teaching using mobile app can mitigate the feeling of loneliness and address socio-psychological factors underpinning sad human period. 


\section{LIMITATIONS}

Due to COVID-19 social restrictions, there were no children involved in the study and therefore the efficacy and usability of the app cannot be generalized as the actual experiences of the learners were not evaluated. There is also a need to further consult and involve teachers, as well as policymakers in the final development of the app.

\section{CONCLUSION AND RECOMMENDATIONS}

There is no doubt that children will learn better through the use of digital media which they are accustomed to especially from early childhood. Therefore, technologists and educators should continuously improve these digital tools to enhance the teaching and learning of young children. Our prototype shows that it is possible to develop simple apps that promote numeracy and local language learning in response to a situation such as the COVID-19 pandemic which disrupted teaching and learning. The purpose of this preliminary study is to demonstrate the potential of apps in supporting the teaching and learning of children when normal school learning is not available due to a natural phenomenon such as the COVID-19 pandemic, or any other situation that makes face-to-face learning impossible. The results of this study can inform policymakers and educators on optimizing technology based early teaching and learning at school and home.

This research contributes to the current discourse related to the introduction of digital technology in low income and developing countries and the promotion of home-based learning. The Ministry of Education could use results of this study to integrate digital tools in pedagogy to improve the skills of the teachers who must deliver content to learners. There is need to reach out to parents who are active partners in the use of the app at home, this may influence adoption of such simple technology in the classroom. The views of teachers and parents can be used in future improvements and development of the app. There is need to conduct more studies on the effects of apps on young children's educational development in low income countries to aid the development of appropriate policies which will inform its integration into the classroom.

Author contributions: All authors were involved in concept, design, collection of data, interpretation, writing, and critically revising the article. All authors approve final version of the article.

Funding: This research was funded by the National Research Fund TTK200318509938.

Declaration of interest: Authors declare no competing interest.

Data availability: Data generated or analysed during this study are available from the authors on request.

\section{REFERENCES}

Akwa, T. E., Ning, T. R., \& Maingi, J. M. (2020). Assessing the Perceptions and Awareness of COVID-19 (Coronavirus) in Cameroon. European Journal of Medical and Educational Technologies, 13(2), em2007. https://doi.org/10.30935/ejmets/8236

Annie, A. (2017, May 3). Discover the Countries Leading in App Usage. Retrieved from global-consumer-appusage-data: https://www.appannie.com/en/insights/market-data/global-consumer-app-usage-data/

Athanaselis, T., Bakamidis, S., Dologlou, I., Argyriou, E. N., \& Symvonis, A. (2014). Making assistive reading tools user friendly: A new platform for Greek dyslexic students empowered by automatic speech recognition. Multimedia Tools and Applications, 68(3), 681-699. https://doi.org/10.1007/s11042-0121073-5

Basilaia, G., \& Kvavadze, D. (2020). Transition to Online Education in Schools during a SARS-CoV-2 Coronavirus (COVID-19) Pandemic in Georgia. Pedagogical Research, 5(4), em0060. https://doi.org/10.29333/pr/7937

Berkowitz, T., Schaeffer, M. W., Maloney, E. A., Peterson, L., Gregor, C., Levine, S. C., \& Beilock, S. L. (2015). Math at home adds up to achievement in school. Science, 350, 196-198. https://doi.org/10.1126/science.aac7427 
Berson, I., \& Berson, M. (2010). High-Tech Tots: Childhood in a Digital World. Charlotte, NC: Information Age Publishing.

Bus, G., Takacs, K., \& Sari, B. (2019). What are we dowloading for our children? Best selling children's apps in four European countries. Journal of Early Childhood Literacy, 19(4), 515-532. https://doi.org/10.1177/1468798417744057

Cabell, Q., Zucker, A., DeCoster, J., Copp, B., \& Landry, S. (2019). Impact of a Parent Text Messaging Program on Pre-Kindergarteners' Literacy Development. AERA Open, 5(1), 1-16. https://doi.org/10.1177/2332858419833339

Center Pew Research. (2018, February 5). Mobile fact sheet. Retrieved from http://www.pewinternet.org/fact-sheet/mobile/

Chaudron, S., Beutel, M. E., Cernikova, M., Donoso-Navarette, V., Dreier, M., Fletcher-Watson, B., \& W€olfling, K. B. (2015). Young children (0-8) and digital technology: a qualitative exploratory study across seven countries. Retrieved from http://publications.jrc.ec.europa.eu/repository/handle/JRC93239

Cheung, C. S., \& Pomerantz, E. M. (2012). Why does parents' involvement enhance children's achievement? The role of parent-oriented motivation. Journal of Educational Psychology, 104(3), 820-832. https://doi.org/10.1037/a0027183

Cohen, M., Hadley, M., \& Frank, M. (2011). Young Children, Apps \& iPad. New York: Michael Cohen.

Cristia, A., \& Seidl, A. (2015). Parental reports on touch screen use in early childhood. PLoS One, 10(6). https://doi.org/10.1371/journal.pone.0128338

Davis, F. D. (1989). Perceived Usefulness, Perceived Ease of Use and User Acceptance of Information Technology. MIS Quarterly. 13, 319-340. https://doi.org/10.2307/249008

Demuyakor, J. (2020). Coronavirus (COVID-19) and Online Learning in Higher Institutions of Education: A Survey of the Perceptions of Ghanaian International Students in China. Online Journal of Communication and Media Technologies, 10(3), e202018. https://doi.org/10.29333/ojcmt/8286

Ebbeck, M., Yim, H., Chan, Y., \& Goh, M. (2016). Singaporean parents' views of their young children's access and use of technological devices. Early Child Educ., 44(2), 127-134. https://doi.org/10.1007/s10643015-0695-4

Elimelech, A., \& Aram, D. (2019). A Digital Early Spelling Game: The Role of Auditory and Visual Support. AERA Open, 5(2), 1-11. https://doi.org/10.1177/2332858419857702

Flewitt, R. (2012). Multimodal perspectives on early childhood literacies. In L. J, \& M. J, The SAGE Handbook of Early Childhood Literacy (pp. 295-310). London: SAGE. https://doi.org/10.4135/9781446247518.n17

Flewitt, R., Messer, D., \& Kucirkova, N. (2015). New directions for early literacy in a digital age: The iPad. Journal of Early Childhood Literacy, 15, 289-310. https://doi.org/10.1177/1468798414533560

Genc, Z. (2014). Parents' perceptions about the mobile technology use of preschool aged children. Procedia Soc. Behav. Sci., 146, 55-60. https://doi.org/10.1016/j.sbspro.2014.08.086

Gordon, A., \& Williams-Browne, K. (2016). Beginnings and Beyond: Foundations in early childhood education. Toronto: Nelson.

Guernsey, L. (2014). Envisioning a Digital Age Architecture for Early Education. Retrieved from New AmericaEducation Policy Program, Washington DC. https://www.newamerica.org/education-policy/policypapers/envisioning-a-digital-age-architecture-for-early-education 
Hoffman, J., \& Paciga, K. (2014). Click, Swipe, and Read: Sharing e-Books with Toddlers and Preschoolers. Early Childhood Education Journal, 42(6), 459-481. https://doi.org/10.1007/s10643-013-0622-5

Jones, C. D. (2015). Effects of writing instruction on kindergarten students' writing achievement: An experimental study. The Journal of Educational Research, 108(1), 35-44. https://doi.org/10.1080/00220671.2013.836466

Kabali, H. K., Irigoyen, M. M., Nunez-Davis, R., Budacki, J. G., Mohanty, S. H., Leister, K. P., \& Bonner, R. (2015). Exposure and use of mobile media devices by young children. Pediatrics, 136, 1044-1050. https://doi.org/10.1542/peds.2015-2151

Kucirkova, N. (2014). iPads in early education: Separating assumptions. and evidence. Frontiers in Psychology, 5, 715-721. https://doi.org/10.3389/fpsyg.2014.00715

Kucirkova, N., \& Zuckerman, B. (2017). A guiding framework for considering touchscreens in children under two. Int. J. Child-Comput. Interact., 12, 40-49. https://doi.org/10.1016/j.ijcci.2017.03.001

Lancaster, H. (2016, July 25). Zimbabwe Telecoms, mobile and broadband - statistics and analyses. Retrieved from https://www.budde.com.au: https://www.budde.com.au/Research/Zimbabwe-TelecomsMobile-and-Broadband-Statistics-and-Analyses

Lee, C., \& Cherner, T. S. (2015). A comprehensive evaluation rubric for assessing instructional apps. Journal of Information Technology Education: Research, 14, 21-53. https://doi.org/10.28945/2097

Livingstone, S., Marsh, J., Plowman, L., Ottovordemgentschenfelde, S., \& Fletcher-Watson, B. (2014). Young children (0-8) and digital technology: a qualitative exploratory study UK. Luxembourg: Joint Research Centre, European Commission.

Lowyck, J. (2014). Bridging learning theories and technology enhanced environments: A critical appraisal of its history. In J. Spector, M. Merrill, J. Elen, \& M. Bishop, Handbook of research on educational communications and technology (pp. 3-20). New York: Springer. https://doi.org/10.1007/978-1-46143185-5_1

Mailizar, A. A., Maulina, S., \& Bruce, S. (2020). Secondary School Mathematics Teachers' Views on E-learning Implementation Barriers during the COVID-19 Pandemic: The Case ofIndonesia. EURASIA Journal of Mathematics, Science and Technology Education, 16(7), 1-9. https://doi.org/10.29333/ejmste/8240

Mangwaya, E., Jeko, I., \& Manyumwa, C. (2013). Availability of Print Curriculum Materials and Its Consequences for the Quality of Education in Schools Located on Newly Resettled Farm Areas in Zimbabwe. Asian Social Science, 9(1), 249-256. https://doi.org/10.5539/ass.v9n1p249

Marsh, J., Plowman, L., Yamada-Rice, D., Bishop, J., Lahmar, J., \& Scott, F. (2018). Play and creativity in young children's use of apps. British Journal of Educational Technology, 49(5), 870-882. https://doi.org/10.1111/bjet.12622

Meyer, M., Adkins, V., Yuan, N., Weeks, H., Chang, Y., \& Radesky, J. (2019). Advertising in young children's apps: A content analysis. Dev. Behav. Pediatr., 40(1), 32-39. https://doi.org/10.1097/DBP.0000000000000622

Neumann, M. (2016). Young children's use of touch screen tablets for writing and reading at home. Relationships with emergent literacy Comput Educ., 97, 61-68. https://doi.org/10.1016/j.compedu.2016.02.013

Nielsen. (2012). American Families See Tablets as Playmate, Teacher and Babysitter. Retrieved from https://www.nielsen.com/us/en/insights/article/2012/american-families-see-tablets-as-playmateteacher-and-babysitter/ 
Nikken, P., \& Schols, M. (2015). How and why parents guide the media use of young children. Journal of Child and Family Studies, 24(11), 3423-3435. https://doi.org/10.1007/s10826-015-0144-4

O'Connor, J. (2016). A threat to childhood innocence or the future of learning? Parents' perspectives on the use of touch-screen technology by 0-3 year-olds in the UK. Contemporary Issues in Early Childhood, 17(2), 235-247. https://doi.org/10.1177/1463949116647290

OCHA. (2020, April 17). Zimbabwe Education Cluster: Humanitarian Response \& COVID-19 Sitrep: 16 April 2020. Retrieved from Zimbabwe: https://reliefweb.int/report/zimbabwe/zimbabwe-educationcluster-humanitarian-response-covid-19-sitrep-16-april-2020

Paivio, A. (2014). Mind and its evolution: A dual coding theoretical approach. New York: Psychology Press. https://doi.org/10.4324/9781315785233

Papadakis, J., \& Kalogiannakis, M. (2017). An evaluation of Greek educational Android apps for preschoolers. 12th Conference of the European Science Education Research Association (ESERA) (pp. 593-603). Researchgate.

Papadakis, S., \& Kalogiannakis, M. (2010). eTwinning in the early childhood as starting line of innovative practices for the didactic of natural sciences. In M. Kalogiannakis, D. Stavrou, \& P. G. Michaelides (Ed.), HSci 2010: 7th international conference hands-on science (pp. 25-31). Crete.

Papadakis, S., Kalogiannakis, M., Orfanakis, V., \& Zaranis, N. (2016). Using scratch and app inventor for teaching introductory programming in secondary education. A case study. International Journal of Technology Enhanced Learning, 8, 217-233. https://doi.org/10.1504/IJTEL.2016.082317

Papadakis, S., Zaranis, N., \& Kalogiannakis, M. (2019). Parental involvement and attitudes towards young Greek children's mobile usage. International Journal of Child-Computer Interaction, 22(2019), 1-12. https://doi.org/10.1016/j.ijcci.2019.100144

Papapicco, C. (2020). Informative Contagion: The Coronavirus (COVID-19) in Italian journalism. Online Journal of Communication and Media Technologies, 10(3), e202014. https://doi.org/10.29333/ojcmt/7938

Paratore, J. R., Cassano, C. M., \& Schickedanz, J. A. (2011). Supporting early (and later) literacy development at home and at school: The long view. In M. L. Kamil, P. D. Pearson, E. B. Moje, \& P. Afflerbach (Eds.), Handbook of reading research (pp. 107-135). New York: Routledge.

Pitchford, J., Kamchedzera, R., Hubber, J., \& Chigeda, L. (2018). Interactive Apps Promote Learning of Basic Mathematics in Children with Special Educational Needs and Disabilities. Front. Psychol, 9(262), 1-14. https://doi.org/10.3389/fpsyg.2018.00262

Plowman, L., Stevenson, O., Stephen, C., \& McPake, J. (2012). Preschool children's learning with technology at home. Comput. Educ, 59(1), 30-37. https://doi.org/10.1016/j.compedu.2011.11.014

Prensky, M. (2010). Teaching digital natives: Partnering for real learning (Vol. 9). Thousand Oaks: Corwin.

Rideout, V. (2017). The Common Sense census: Media use by kids age zero to eight. Retrieved from https://www.commonsensemedia.org/sites/default/files/uploads/research/csm_zerotoeight_fullrep ort_release_2.pdf

Roser, M., Ritchie, H., Ortiz-Ospina, E., \& Hasell, J. (2020, April 27). Coronavirus Pandemic (COVID-19). Retrieved from OurWorldInData.org: https://ourworldindata.org/coronavirus\#citation

Simon, F., Nemeth, K., \& McManis, D. (2013). Technology in ECE classrooms: Results of a new survey and implications for the field. Exchange, 35(5), 68-75.

Sintema, E. J. (2020). Effect of COVID-19 on the Performance of Grade 12 Students: Implications for STEM Education. Eurasia Journal of Mathematics, Science and Technology Education, 16(7), em1851. https://doi.org/10.29333/ejmste/7893 
Stephen, C., Stevenson, O., \& Adey, C. (2013). Young children engaged with technologies at home: The influence of family context. Journal of Early Childhood Research, 11(2), 149-164. https://doi.org/10.1177/1476718X12466215

Strouse, A., \& Ganea, P. (2017). Parent-Toddler Behavior and Language Differ When Reading Electronic and Print Picture Books. Frontiers in Psychology, 8, 1-14. https://doi.org/10.3389/fpsyg.2017.00677

SundayNews. (2020, April 26). Pupils to receive lessons through radio. Retrieved from https://www.sundaynews.co.zw/category/local/: https://www.sundaynews.co.zw/pupils-to-receivelessons-through-radio/

Tanhan, A., Yavuz, K., Young, J., Nalbant, A., Arslan, G., Yıldırım, M., ... Çiçek, I. (2020). A Proposed Framework Based on Literature Review of Online Contextual Mental Health Services to Enhance Wellbeing and Address Psychopathology During COVID-19. Electonic Journal on Gen Med, 17(6), em254. https://doi.org/10.29333/ejgm/8316

UNICEF. (2020, February 19). Humanitarian Appeal Revision. Retrieved from unicef.org/zimbabwe/media: https://www.unicef.org/zimbabwe/media/1921/file/Revised\%20Zimbabwe\%20Flash\%20Appeal.pdf

Usak, M., Masalimova, A. R., Cherdymova, E. I., \& Shaidullina, A. R. (2020). New playmaker in science education: COVID-19. Journal of Baltic Science Education, 19(2), 180-185. https://doi.org/10.33225/jbse/20.19.180

Vanderloo, L. (2014). Screen viewing among preschoolers in childcare: A systematic review. BMC Paediatrics. https://doi.org/10.1186/1471-2431-14-205

Vittrup, B., Snider, S., Rose, K., \& Rippy, J. (2014). Parental perceptions of the role of media and technology in their young children's lives. Journal of Early Childhood Research, 14(1), 43-54. https://doi.org/10.1177/1476718X14523749

Zaranis, N., Kalogiannakis, M., \& Papadakis, S. (2013). Using Mobile Devices for Teaching Realistic Mathematics in Kindergarten Education. Creative Education, 4(7A1), 1-10. https://doi.org/10.4236/ce.2013.47A1001

Correspondence: Vusumuzi Maphosa, Lupane State University, Department of ICT, Zimbabwe.

E-mail:v.maphosa@gmail.com 